Леванцэвіч, Лена. «Мясцовы кампанент у мастацкім ідыялекце пісьменнікаў Брэстчыны». Лінгвостилістичні студії, вип. 11, 2019, с. 79-88.

Levantsevich, Lena. "Local Component in the Literary Idiolect of the Writers from Brest Region". Linguostylistic Studies, iss. 11, 2019, pp. 79-88.

УдК 811.161.3

https://doi.org/10.29038/2413-0923-2019-11-79-88

\title{
МЯСЦОВЫ КАМПАНЕНТ У МАСТАЦКІМ ІДЫЯЛЕКЦЕ ПІСЬМЕННІКАЎ БРЭСТЧЫНЫ
}

\author{
Лена Леванцэвіч \\ Брэсцкі дзяржаўны ўніверсітэт імя А. С. Пушкіна, \\ Брэст, Рэспубліка Беларусь
}

У артыкуле прааналізаваны дыялектызмы ў мастацкім кантэксце пісьменнікаў Брэстчыны. У мастацкім ідыялекце моўная спецыфіка аўтара прадугледжвае выкарыстанне дыялектызмаў як кампанента аўтарскай моўнай сістэмы. Вызначана функцыя мясцовай моўнай адзінкі (устойлівых адзінак, дыялектызмаў, устарэлых слоў) у ідыялекце пісьменнікаў Брэстчыны; прааналізаваны структурна-семантычныя асаблівасці дыялектызмаў. Выяўлена адметнасць ужывання розных тыпаў дыялектызмаў такімі аўтарамі, як У. Гніламёдавым, Г. Марчуком, М. Купрэевым. Пісьменнікі Брэстчыны ўводзяць дыялектнае слова ў мастацкі кантэкст звычайна шляхам «цытавання», прысутнасці дыялектызмаў у кантэксце як іншастылёвага элемента.

Ключові слова: мастацкі ідыялект, дыялектызм, устойлівы выраз, устарэлае слова.

\section{МІСЦЕВИЙ КОМПОНЕНТ У ХУДОЖНЬОМУ ІДІОЛЕКТІ ПИСЬМЕННИКІВ БЕРЕСТЕЙЩИНИ}

У статті проаналізовано діалектизми в художньому контексті письменників Берестейщини. У художньому ідіалекті мовна специфіка письменника передбачає використання діалектизмів як компонента авторської мовної системи. Визначено функції місцевих мовних одиниць (фразеологізмів, діалектизмів, застарілих слів) в ідіалекті письменників Берестейщини; проаналізовано структурно-семантичні особливості діалектизмів. Виявлено специфіку вживання різних типів діалектизмів такими авторами, як В. Гниломедов, Г. Марчук, Н. Купреєв. Письменники Берестейщини вводять діалектні слова в художній контекст зазвичай шляхом «цитування», присутності діалектизмів у контексті як елементів іншого стилю.

Ключові слова: художній ідіолект, діалектизм, фразеологізм, застаріле слово.

\section{LOCAL COMPONENT IN THE LITERARY IDIOLECT OF THE WRITERS FROM BREST REGION Lena Levantsevich \\ Brest State A. S. Pushkin University, Brest, Republic of Belarus}

\footnotetext{
( ) Леванцэвіч Л., Східноєвропейський національний університет імені Лесі Українки, 2019.
}

Це стаття відкритого доступу на умовах CC BY-NC 4.0 
Modern studies of the writers' individual style features lay emphasis on the importance of elucidating the creative approach to the issues of native speakers' language means and introducing dialectisms in the artistic texts. Taking into account that artistic languge is intrinsic for the activity of artists of the world, the author's usage of communication means is always associated with his perception of the world, and his sense of language. In literary idiolect, the author's linguistic specification provides for the usage of dialectism as a component of the author's language system. The article analyzes the dialects in the artistic context of the Brest region writers (V. Hnilomedova, G. Marchuk, N. Kupreiev).The emphasis iis laid on the functions of the local language units (set expressions, dialectisms, obsolete words) in the idiolect of the Brest region writers. The author analyzes the structural and semantic features of dialectisms. The issues of function and semantics of dialectisms, obsolete words and set expressions in the idiolect of the writers of Brest region are topical since few attempts have been made to investigate them. With the help of outdated words and ethnographic dialectisms, the writers convey historical events, the life of Bresteians, the ethnographic originality of the Western Belarus village in the 20s of the twentieth century. The The study has revealed peculiar features of the usage of dialectisms at different levels (phonetic, grammatical, word-forming, lexical and semantic). The peculiarity of the the characters' speech in the literary works is conveyed via the usage of phonetic, grammatical and word-forming dialectisms. Brest region writers introduce dialect words into the literary context usually by «quoting», therefore the presence of dialectisms in the text is an element of another style. The article highlights two main functions of a dialect word in an artistic context: firstly, for realistic reflection of village life and creation of ethnographic colouring; and secondly, as the language characteristics of the literary work characters and for the individualization of speech.

Key words: literary idiolect, dialecticism, set expression, obsolete word.

Уступ. Адной з актуальных тэм, да якой звяртаюцца лінгвісты, з'яўляецца вывучэнне мовы мастацкай літаратуры. На сучасным этапе даследавання мовы твораў пэўных пісьменнікаў адчуваецца патрэба ў вызначэнні творчых адносін носьбітаў мовы да тых моўных сродкаў, якія яны выкарыстоўваюць. Улічваючы, што мастацкае маўленне - гэта дзейнасць мастакоў слова, выкарыстанне сродкаў камунікацыі заўсёды звязана са схільнасцямі пісьменніка, яго светабачаннем і адчуваннем мовы. Таму ў філалогіі стаў выкарыстоўвацца тэрмін «мастацкі ідыялект», сукупнасць кампанентаў аўтарскай моўнай сістэмы. Пры даследаванні мастацкага ідыялекту звяртаецца ўвага і на асаблівасці ўжывання аўтарам дыялектных слоў (дыялектызмаў) і ўстойлівых адзінак. Побач з тэрмінам дыялектызм ужываюцца намінацыі правінцыялізм, лакалізм, абласное слова, мясцовае слова і інш.

Пры ўжыванні дыялектнага слова ў мастацкім кантэксце варта адрозніваць «цытаванне», наяўнасць дыялектызмаў у кантэксце як іншастылёвага элемента, i выкарыстанне дыялектызмаў нароўні 3 лексікай літаратурнай мовы.

Тыпы дыялектызмаў, спосабы іх уключэння ў мастацкі кантэкст даследаваліся навукоўцамі на аснове мовы твораў І. Пташнікава, Б. Сачанкі, В. Быкава, М. Зарэцкага, У. Калесніка, Ф.Янкоўскага і інш. Вынікам навуковага даследавання дыялектызмаў у мастацкім кантэксце 
М. Абабуркам стаў слоўнік «Дыялектызмы ў творах беларускіх савецкіх пісьменнікаў. Кароткі слоўнік-даведнік». Мясцовы моўны кампанент (дыялектызм, устарэлае слова, устойлівы выраз) у мастацкім ідыялекце пісьменнікаў Брэстчыны да гэтага часу не з'яўляўся аб'ектам комплекснага даследавання.

Пры выкананні задання «Лінгвістычнае краязнаўства Брэстчыны: узаемадзеянне мовы і культуры» (№ ДР 20160434, 2016-2020 гг.) дзяржаўнай праграмы навуковых даследаванняў намі праводзіўся адбор, аналіз і сістэматызацыя мясцовых моўных адзінак, ужытых пісьменнікамі Брэстчыны (У. Гніламёдавым, Г. Марчуком, М. Купрэевым, I. Сычыкам). Улічваючы лінгвакультуралагічны аспект нашага даследавання, мы аналізуем наступныя групы мясцовых моўных адзінак, ужытых пісьменнікамі-берасцейцамі у (словаўтваральныя, граматычныя, фанетычныя, семантычныя, лексічныя (этнаграфічныя), устойлівыя выразы, моўнаэтыкетныя формулы, словы 3 суфіксамі суб'ектыўнай ацэкі, часціцы, гукаперайманні, звароты, саветызмы, устарэлыя словы, онімы (мянушкі, мікратапонімы, неафіцыйныя імёны, заонімы), асацыятыўныя лакуны, а таксама кантэксты, якія характарызуюць светапогляд берасцейцаў (прыметы, павер'i, назіранні, філасофскія заключэнні).

Мэта даследавання - вызначыць функцыю мясцовага кампанента ў мастацкім ідыялекце пісьменнікаў Брэстчыны; вызначыць структурнасемантычныя асаблівасці дыялектызмаў.

Матэрыял i метады даследавання. Для навуковага аналізу выбраны і сістэматызаваны фактычны матэрыял (устарэлыя словы, дыялектызмы, фразеалагізмы, прыказкі) 3 раманаў i аповесцяў У. Гніламёдава, Г. Марчука і М. Купрэева.

Для канстатацыі, апісанняя моўных фактаў (мясцовага моўнага кампанента) у мастацкім ідыялекце пісьменнікаў Брэстчыны выкарыстаны апісальны метад. Метад кампанентнага аналізу часткова выкарыстоўваўся пры даследаванні фанетычных і граматычных дыялектных з'яў.

Да дыялектных кампанентаў аўтарскай моўнай сістэмы, якія вызначаюць індывідуальныя мадэлі і спецыфіку выкарыстання агульнанародных сродкаў, выяўляюць іх ролю ў аўтарскай рэпрэзентацыі i паказваюць нацыянальна-культурную спецыфіку мовы, найперш мы адносім усе тыпы дыялектызмаў (словаўтваральныя, граматычныя, фанетычныя, семантычныя, лексічныя (этнаграфічныя) і устойлівыя выразы.

Адметнасці маўлення герояў твора перадаюцца праз выкарыстанне фанетычных, граматычных і словаўтваральных дыялектызмаў. Зразумела, што пры ўвядзенні ў мастацкі кантэкст фанетычных і граматычных дыялектызмаў, кожны пісьменнік выкарыстоўвае дыялектныя асаблівасці той мясцовасці, адкуль ён родам: У. Гніламёдаў нарадзіўся на 
Камянеччыне, Г. Марчук родам са Століншчыны, дзяцінства і юнацтва М. Купрэева прайшло на Бярозаўшчыне. Гаворкі названых рэгіёнаў адносяцца да загародскага тыпу заходнепалескіх гаворак.

Праз мову герояў паказваюцца наступныя характэрныя фанетычныя і граматычныя асаблівасці загародскіх гаворак:

ужыванне клічнага склону назоўнікаў у функцыі зваротка: $-A$ чому дахаты ідзеш, Карнейко? - пытае Канцуб (Марчук, Кветкі (2004) 298);

канчатка -ове ў назоўным склоне множнага ліку адушаўлёных назоўнікаў: - Ой, людкове! - пляснула рукамі напалоханая Хомчыха (Гніламёдаў, Вяртанне 5);

канчатак -мо дзеясловаў абвеснага і загаднага ладу першай асобы множнага ліку: - А то едзьмо з намі, яй-бо (Марчук, Кветкі (2004) 36); Хадземо, мамо. Бяры касу, - казала дачка (Марчук, Кветкі (2004) 301); Пайшлі на сенажаць. Косімо (Марчук, Кветкі (2004) 72).

ужыванне інфінітава з суфіксам -ці: Кажу: Маня, шчо так жыці, хадземо да маіх (Купрэеў, Палеская 133).

галосны [i] на месцы ранейшага *h: A ўжэ одсіль ліс машыны повэзуть на станцыю, на Бронную Гору" (Купрэеў, Палеская 59).

оканне: - Олена поставіла на газ бульбу, побегла да ракі, навудзіла рыбы, вярнулася, дык яшчэ і бульба ў гаршку не зварылася (Марчук, Кветкі (2004) 385).

М. Купрэеў, каб паказаць адметнасць заходнепалескай гаворкі, уводзіць у дыялагічнае маўленне герояў цэлыя фразы на дыялектнай мове: Дэржысь, Толя! Зящем маім будэш... (Купрэеў, Палеская 58); Хлопцы! За гозэро прыгналі немцау. Палонныя. Воны там будуць рэзаць ліс. Потым дэрыво воны по гозэры пэрэгоняць сюды. А ўжэ одсіль ліс машыны повэзуть на станцыю, на Бронную Гору (Купрэеў, Палеская 59). Хаця чыстым дыялектным маўленнем прыведзеныя кантэксты таксама нельга лічыць, бо аўтар кантамінуе дыялектныя фанетычныя рысы і рысы літаратурнай мовы, напрыклад, у паўночназагародскай групе загародскіх гаворках, да якіх адносіцца гаворка в. Пескі Бярозаўскага раёна, адсутнічае цеканне (у праведзеным жа кантэксце - зяцем, будуць, рэзаць, але повэзуть); гаворка, як і ўсе заходнепалескія, адносіцца да окаючых, аднак у маўленні героя оканне перадаецца непаслядоўна: гозэро, воны, дэрыво, але маім, палонныя).

Для вяскоўцаў, якія нарадзіліся ў 30-я гады XX ст. і з'яўляюцца непісьменнымі або малапісьменнымі (не маюць пачатковай і сярэдняй адукацыі або закончылі адзін або некалькі класаў пачатковай школы) выклікала і выклікае цяжкасці асваенне запазычаных слоў, русізмаў. Гэтая адметнасць маўлення дзеючых асоб таксама перадаецца пісьменнікамі Брэстчыны: - Нейкія ў иябе, Адась, тухлі модныя? (Марчук, Кветкі (2004) 159); - Шчо праўда, то праўда. У горадзе ўсё купляющь. А скажы, Карнейко, шчо па тым целявізары кажуць, будзе вайна ці не? (Марчук, Кветкі (2004) 298). 
Зрэдку сустракаюцца ў творах берасцейцаў і словаўтваральныя дыялектызмы. Як правіла, яны адрозніваюцца ад літаратурных слоў пэўнымі суфіксамі: Браў на абед у кішэню чакушачку, наліваў сто грам $i$ там высока, на рыштаваннях, з апетытам за здароўе папа і дыякана выпіваў (Марчук, Кветкі (2004) 91); Скрынку з дакументамі закопвалі ўжо прысмеркамі, калі чырвонае сонца амаль поўнасцю схавалася за карчы, за альшыну (Гніламёдаў, Вяртанне 25).

Адметнасцю ідыялекту пісьменнікаў Берасцейшчыны з'яўляецца ўжыванне лексічных і семантычных дыялектызмаў. Найбольшую пашыранасць набылі дыялектызмы-назоўнікі, якія абазначаюць абстрактныя паняцці, прадметы побыту, з'явы прыроды, адзнакі рэльефу, прадукты харчавання, назвы асоб: вэсна 'перыяд выезду на базар для продажу насення кветак': - А шчо, на вэсне таргаваць насеннем лягчэй? (Марчук, Кветкі (2004) 33); склеп 'труна' Справа ў тым, што стары Юрко (яго хата стаяла насупраць нашай) рабіу скляпы i гатовыя (а іх было заўсёды тры-чатыры штукі) складвау пад павець якраз перад нашымі вокнамі (Марчук, Кветкі (2004) 54); капорэ 'слова, якое ўжываецца, калі размова ідзе пра нешта неістотнае, не самае важнае': Але капорэ, Бог з ім, не судзіце і не судзімы будзеце (Марчук, Кветкі (2004) 70); фортка 'калітка': Так мы разам і праводзілі Цялегіну да форткі (Марчук, Кветкі (2004) 87); хлюшч 'лівень': - А што такое робіцца, сіла нябесна. Ілье, бу хлюшч улетку, на парозе яшчэ кажа баба (Марчук, Кветкі (2004) 160); прычэпа 'жанчына, якая жыве з мужчынам без шлюбу': Хтосьці сказаў: - Прычэпа! Прычэпай у Прусцы называлі жанчыну, якая жыла з мужчынам без шлюбу (Гніламёдаў, Вайна 7); кавенька 'кульбака': Яго параніла ў нагу, i з таго часу Фэдар карыстаўся кавенькай (Гніламёдаў, Вайна 13); жырыло 'балаціна, лужына': За вёскай, у жырыле, трывожна азваліся, закракталі жабы, нібы таксама прадчуваючы нешта нядобрае (Гніламёдаў, Вайна 4); гічка 'бацвінне': Тактыка, браце, такая ёсць. Напхаць у мяшок $i$ завязаць, гічкай зашмаргнуць (Гніламёдаў, Вайна 15); столак 'зэдлік, кароткая лаўка': Паставілі стол, які Фёкла накрыла абрусам, некалькі столакаў (Гніламёдаў, Вайна 32); падсмеценне 'частка малака, якое аддзяляе вяршкі і малако пры адстойванні': Гаспадыня прапанавала суп са шчаўя, забеленага падсмеценнем, і ячную кашу (Гніламёдаў, Вайна 32).

у лексічнай структуры ідыялекту пісьменнікаў Брэстчыны зрэдку ўжываюцца прыметнікавыя i дзеяслоўныя формы (звычайна такія лексемы маюць эмацыянальна-экспрэсіўную афарбоўку): негадзяшчы 'дрэнны, слабы': Памяць мая зрабілася зусім негадзяшчая (Марчук, Кветкі (2004) 235); датумкаць 'зразумець': - Мы з ім такія сваякі, што мой дзед яго бабцы насіў гаўно у шапџы, - адказаў Свісціян, кладучыся ў пасцель, каб даспаць ноч. - Датумкала? (Гніламёдаў, Вайна 20); лешыць 'пазначаць на загоне месца, дзе ўжо пасеяна, каб насенне не кідаць два разы ў адно і тое ж месца': - 3 бацькам лён сеялі. Я дапамагала, загоны лешыла (Гніламёдаў, Вайна 233). 
Для перадачы гістарычных падзей у Заходняй Беларусі 20-х гадоў XX ст., стварэння запамінальных вобразаў і характараў, адлюстравання каларыту вёскі У. Гніламёдаў выкарыстоўвае гістарызмы: балахоўцы 'узброеныя фарміраванні перыяду грамадзянскай вайны (забытыя атрады)': Тут быў адзін балаховец вучоны, дык ён казаў: "панеспадар" (Гніламёдаў, Вяртанне 27); закуцнік 'судовы выканаўца': Каля пана секвестратара стаяў пан закуцнік - судовы выканаўца. Апанас, Хомчышын сын, са спалоханым выглядам моўчкі назіраў, як закуцнік з паліцыянтам выганялі з хлява карову (Гніламёдаў, Вяртанне 47); уланы 'разам з гусарамі род лёгкаўзброенай новаеўрапейскай кавалерыі, узброены пікамі, шаблямі і пісталетамі', секвестар 'дзяржаўны служачы': Глядзіце ў мяне! Акажаце ўпр - уланаў прышлю! - набычыўся ў адказ секвестратар (Гніламёдаў, Вяртанне 48); пацыфікацыя 'падаўленне карнымі мерамі паўстання, народнага хвалявання': Я выклічу кампанію жалнераў! Я правяду пацыфікацыю! Я хату разламаю! (Гніламёдаў, Вяртанне 48); пастарунак 'мясцовае аддзяленне паліцы ў заходняй Беларусі да 1939 г.': “Першае нагнаць страху", - вырашылі ў паліцэйскім пастарунку (Гніламёдаў, Вяртанне 49); неправамысльныя 'спісы западозраных': A пакуль што давядзещца прозвішча пана унесці ў лісты неправамысльных (Гніламёдаў, Вяртанне 53); шарваркі 'грамадская працоўная павіннасць пераважна па будаўніцтву і рамонту дарог, мастоў, грэбляў, панскіх будоўляў': Летам $i$ пад восень прускаўцам даводзілася адрабляць шарваркі (Гніламёдаў, Вяртанне 83).

Прысутнасць польскай улады на Камянеччыне падкрэсліваецца і ўжываннем польскіх лексем: жонд 'савет, даемны ўрад': Жонд польскі задужа шмат грошы выдаткоўвае на войска і паліцыю, - заўважыў Амбожый (Гніламёдаў, Вяртанне 59); ужэнднік 'чыноўнік': Там, побач з легкавым аўтамабілем - таксоўкай, як яго тут называлі, - стаяў нейкі ўжэнднік у акулярах з партфелем у руцэ (Гніламёдаў, Вяртанне 47); дзвонэк 'званочак': A дзвонэк? - папытаў другі паліцыянт (Гніламёдаў, Вяртанне 44).

М. Купрэеў, паказваючы пасляваеннае жыццё на Бярозаўшчыне, таксама ўводзіць у мастацкі кантэкст гістарызмы: керагаз 'від бясшумнага прымуса, у якім згарае газа', фінагент 'фінансавы агент': <..> мачыха на керагазе, на вялікай патэльні будзе смажыць рыбу <...> і ў хату ўсунецца тоўсты і высокі, на ўвесь праём у дзвярах, доктар, за ім убяжыць маленькі фінагент у сініх галіфэ, бліскучых ботах<...> (Купрэеў, Палеская 57).

Г. Марчуку пры дапамозе ўжывання сінонімаў удаецца ў прасторы i часе паказаць працэс замены ўстарэлых слоў на новыя: Гэта адбылося каля Шпронькавай лаўкі, якую ияпер называлі магазінам і якая раней належала Міколу Шпроньку, а з верасня 1939 года Саветы зрабілі яе дзяржаўнай (Марчук, Кветкі (2004) 5).

Пры дапамозе архаізмаў і этнаграфічных дыялектызмаў мастакамі слова перадаецца побыт берасцейцаў першай паловы XX ст.: гатка 'пляцень, якім умацоўваюць бераг ракі', крушні 'кучы камення': Царква 
каменная (яна сюды хадзіла), царква драўляная (i ў ёй малілася), чырванашчокі касцёл, які з трыццаць дзевятага года не дзейнічае, нізенькія драўляныя масткі і зноў хаты, хаты з адным, двума вокнамі на вуліиу, гаткі, сплещеныя з лазы, і крушні ля гліністых берагоў, брукаваны шлях, у канцы якога мураваныя дамы (Марчук, Кветкі (2004) 9); вэрхнік 'тоўстая пуховая коўдра': Гарадчукі будавалі хаты, крылі іх чаротам, саломай, дранкай, масцілі гаткамі берагі бурлівай і часам неспакойнай Гарыні, рэзалі з золата завушніцы, выпілоўвалі пярсцёнкі, рабілі лодкі, дзяўблі чоўны, падкоўвалі коней, набівалі падушкі і вэрхнікі, малявалі іконы - тут роўных не было Глебу Іванавічу, як раней яго бацьку і дзеду, рабілі на святы цукровую вату і лёды (Марчук, Кветкі (2004) 25); коц 'тонкая скураная коўдра': Адна толькі прускаўская Амелія, акрыўшы плечы коцам, бегала вакол задзір і енчыа (Гніламёдаў, Вайна 6); дваяны 'від гліняных гаршчкоў': Полудзень прынесла Фёкла - боршч у дваянах, варанае сала, свежыя агуркі, завернуты ў хрэнавы ліст сыр, хлеб (Гніламёдаў, Вайна 46); чосанкі 'валёнкі з воўны': Заадно трэба было і Фёкле новыя чосанкі заказаць (Гніламёдаў, Вайна 62).

Ва ўстойлівых выразах, якія выкарыстоўваюць Г. Марчук і У. Гніламёдаў пры апісанні паўсядзённага жыцця сваіх герояў, занатаваліся разнастайныя жыццёвыя заканамернасці, правілы, парады на розныя жыццёвыя выпадкі, перасцярогі ў момант небяспекі: - Гэта ж чаму? Што я воспай мечаны. У нас па канстытуцыі кожны мае права на вучобу (Марчук, Кветкі (1988) 366); Ты кажаш, народу лягчэй будзе? Павялічыщца план <..> Ды элементарна нашы землі не вытрымаюць, калі нават людзі будуць гараваць у тры пагібелі (Марчук, Кветкі (1988) 372); Прагнаму два разы баліць жывот: спачатку ад голаду, потым ад абжорства (Гніламёдаў, Вайна 303); У Павалу шмат дабраты і зычлівасці. Пра такіх кажуць: «У кулаку з яйка кураня выведзе» (Гніламёдаў, Вайна 117). Мой Амброжый часам кажа сваёй Стэпе: "Дзякуй Богу, хлеб удаўся, пад скарынку кот схаваўся». Тая злуе, але хлеб пячы не ўмее (Гніламёдаў, Вайна 33); Смерці не падперці, - адгукнуўся нехта на ўздыханні Калоды, і на гэтым усё скончылася (Гніламёдаў, Вайна 267).

у палешукоў свае адносіны да жыцця і смерці, што перадаецца ў выразах: - Дзіцятка, - супакойвае яе нянечка, - гасподзь даў, гасподзь і ўзяў (Марчук, Кветкі (1988) 365); - Адасік, плакаць ужо не трэба. Бог даў, Бог узяў. Гэто доля така, - казала мне баба Лісавета (Марчук, Кветкі (2004) 21).

Пісьменнікі добра ведаюць свой народ, засвоілі і асэнсавалі яго назіральнасць, што правяралася не адным пакаленнем і вылілася ў мудрыя разважанні. Вуснамі герояў твора аўтары проста і мудра выказваюць сваё і іх светабачанне: Мне падалося, што пасля размовы з ім з плеч маіх знялі цяжкі камень і ўзвалілі торбу з пяском (Марчук, Кветкі (2004) 239); Бывае пітво гідота, а не адарвеш ад рота! Так і наша жыщцё. Міне забава, і я буду пава. Так шчо, чалавеча, не судзі мяне, калі не жывеш адным са мною жыццём (Марчук, Кветкі (2004) 258); I вось пахаванне, як снег у спякоту 
(Марчук, Кветкі (2004) 14). Тыдзень заставаўся да сенакосу - была тая пара, калі, як казалі у Прусцы, зязюля падавілася ячменным коласам. Стаяла нясцерпная гарачыня (Гніламёдаў, Вайна 4).

Спосабы ўвядзення дыялектнага слова ў мастацкі кантэкст розныя. У. Гніламёдаў выкарыстовае так званыя традыцыйныя дыялектызмы, якія не трэба тлумачыць, таму што яны неаднойчы сустракаюцца ў творах пісьменнікаў розных пакаленняў. Некаторыя 3 такіх дыялектызмаў памечаны ў “Тлумачальным слоўніку беларускай мовы” як абласныя: варункі 'абставіны, умовы': Не ведаю, дзе мы возьмем і як быщь пры такіх варунках <..> (Гніламёдаў, Вяртанне 28); котлішча 1) 'месца жыхарства, сяліба'; 2) 'род, сям'я': Лявон глядзеў доўга на роднае котлішча (Гніламёдаў, Вяртанне 7).

Любому чытачу, якія ведае беларускую літаратурную мову, зразумелыя фанетычныя, граматычныя і словаўтваральныя дыялектызмы.

Увядзенне дыялектызмаў іншы раз не патрабуе спецыяльных тлумачэнняў па той прычыне, што сэнс іх лёгка вызначаецца па семантыцы асобных частак агульнавядомых літаратурных слоў: неправамысльныя: А пакуль што давядзецца прозвішча пана ўнесці ў лісты неправамысльных (Гніламёдаў, Вяртанне 53); варыўца: Падарэце калеку! пачулася з-за акна. - можа, хоць варыўца сырога (Гніламёдаў, Вяртанне 62); спічасты: Нейкі чырвонаармеец у вастраверхай спічастай шапцы, які пастаянна знаходзіуся пры камісару, так і адрэзаў: - Панская бярлога нам ні к чаму (Гніламёдаў, Вяртанне 15); борацца: Ім не да нас, яны паміж сабой бораюцца (Гніламёдаў, Вяртанне 12).

Часта значэнне дыялектызмаў становіцца зразумелым з мастацкага кантэксту: безваладзь 'адсутнасць улады' - у Прусцы безваладзь! Хвядзюшка падняў вочы і няуцямна паглядзеў на сябрука. - Улады - аніякай! (Гніламёдаў, Вяртанне 18); Неўкач 'некалі, неяк, аднойчы' - От жытка, цьфу на яе. Заказаў мне Міхалка неўкач на кажух аўчыны. Кажа, знайдзі, я куплю (Марчук, Кветкі (1988) 195).

Аднак, бываюць выпадкі ўвядзення ў мастацкі кантэкст дыялектнага слова без яго тлумачэння, i, каб зразумець значэнне слова, а часам i правільна ўспрыняць змест выказвання, чытачу патрэбна карыстацца дыялектным слоўнікам: ківенька - Адна, меншая, брала з сабою ў горад ківеньку (яны на святы выбіраліся да царквы, хоць і былі каталічкамі) (Марчук, Кветкі (2004) 40); жак - Сам здаўна плёу кашы, жакі, валізкі, лапці, рабіў граблі і дзіцячыя калыскі, дзяуббаў чаўны і карыты - з чаго і жыў (Марчук, Кветкі (2004) 52) (ківенька 'кульбака', жак 'рыбалоўная снасць у выглядзе нацягнутай на абруч сеткі').

Любы дыялектызм, ці то ў аўтарскай мове, ці то ў мове героя павінен быць максімальна зразумелым для чытача. Сапраўдныя майстры мастацкага слова разумеюць, што многія назвы прадметаў, працэсаў, якасцей прадметаў вядомыя ў адной мясцовасці і невядомыя ў другой, 
таму яны клапоцяцца пра іх зразумеласць, даходлівасць, карыстаюцца рознымі прыёмамі і спосабамі ўвядзення дыялектнага слова ў мову мастацкага твора. Найчасцей дыялектныя словы выкарыстоўваюцца мастакамі слова для таго, каб праўдзіва і вобразна паказаць месца, дзе адбываецца дзеянне, адлюстраваць асяроддзе і атмасферу, што акаляе героя, уплывае на фарміраванне яго характару, светапогляду.

Вынікі і перспектывы даследавання: Моўная спецыфіка аўтара прадугледжвае выкарыстанне ў мастацкім ідыялекце дыялектызмаў як кампанента аўтарскай моўнай сістэмы. Можна вызначыць дзве асноўныя функцыі дыялектнага слова ў мастацкім кантэксце: а) для стварэння мясцовага каларыту і рэалістычнага паказу жыцця вёскі; б) для індывідуалізацыі маўлення і моўнай характарыстыкі герояў літаратурных твораў.

Берасцейскія аўтары з усіх відаў мясцовых кампанентаў уводзяць у мастацкі кантэкст найперш устарэлыя словы, лексічныя і семантычныя дыялектызмы, прыказкі і фразеалагізмы. Пры ўжыванні фанетычных дыялектызмаў аўтары перадаюць не ўсе фанетычныя асаблівасці гаворкі нават у межах адной лексемы (атрымліваецца «частковае літаратурнае асваенне» дыялектнага слова).

На працягу многіх стагоддзяў вёска была захавальніцай самабытных народных традыцый, што стварала грунт для нацыянальнага адраджэння і этнічнага самавызначэння беларускага народа. Мясцовае слова адлюстроўвае працэс засялення і асваення этнічнага абшару, развіцця вытворчых сіл і сацыяльна-эканамічных адносін, зменлівую этнічную сітуацыю. Так як мова цесна звязана з гісторыяй і культурай народа, то ў моўных адзінках «захаваліся» асаблівасці ландшафту, побыту, культуры, сацыяльна-эканамічных зменаў. Адным са шляхоў захавання такой лексікі і ў будучым папаўнення слоўніка літаратурнай мовы з'яўляецца ўжыванне пісьменнікамі пэўнага рэгіёну дыялектных слоў у сваіх творах. У перспектыве вывучэння такой лексікі - працяг працы В. Абабуркі, складанне слоўнікаў дыялектызмаў у мастацкай літаратуры, як гэта робіць ва ўкраінскім мовазнаўстве прафесар Г. Аркушын.

\section{Список використаної літератури}

Абабурка, Мікалай. Дыялектызмы ў творах беларускіх савецкіх пісьменнікаў: кароткі слоўнік-даведнік. Мінск: Вышэйшая школа, 1979.

Аркушин, Григорій. Словник західнополіських діалектизмів у художній літературі. Луцьк, 2018.

Гніламёдаў, Уладзімір. Вайна, раман. Мінск: Беларуская навука, 2014.

Гніламёдаў, Уладзімір. Вяртанне: раман. Мінск: Мастацкая літаратура, 2008.

Купрэеў, Мікола. Палеская элегія: аповесці. Мінск: Литература и Искусство, 2007.

Марчук, Георгій. Кветкі правінцыі: раман, аповесць. Мінск: Мастацкая літаратура, 1988.

Марчук, Георгій. Кветкі правінцыі: раман, навелы, афарызмы. Мінск: Мастацкая літаратура, 2004. 


\section{References}

Ababurka, Mikalaj. Dyaljektyzmy u tvorach bjelaruskich savjeckich pis'mjennikau: karotki slounik-davjednik. Minsk: Vysejsaja skola, 1979.

Arkushyn, Hryhorii. Slovnyk zakhidnopoliskykh dialektyzmiv u khudozhnii literaturi. Lutsk, 2018.

Hnilamjodau, Uladzimir. Vajna. Minsk: Bjelaruskaja navuka, 2014.

Hnilamjodau, Uladzimir. Vjartannje. Minsk: Mastackaja litaratura, 2008.

Kuprejeu, Mikola. Paljecrfja eljegija. Minsk: Literatura i Iskusstvo. 2007.

Marcuk, Hjeorhij. Kvjetki pravinyi. Minsk: Mastackaja litaratura, 1988.

Marcuk, Hjeorhij. Kvjetki pravinyi. Minsk: Mastackaja litaratura, 2004.

Стаття надійшла до редколегії 04.09.2019 